\title{
KNOWLEDGE AND COPING DURING COVID-19: A report of an extension experience report at the Sateré-Mawé Association of Indigenous Women (AMISM), Manaus, AM
}

\author{
Joelma Monteiro de Carvalhoa \\ Rejane Gomes Ferreirab \\ Rucian da Silva Vilácioc \\ Vanessa do Nascimento Damascenod
}

\begin{abstract}
This report describes the daily routine of the Sateré-Mawe Indigenous Women's Association (AMISM) in the context of the Covid-19 pandemic. The predominant activity of the Association is producing indigenous handicrafts, but with the pandemic, its members had to find strategies for maintenance and survival, faced with the humanitarian health crisis and the consequent economic impacts on the group's activities. This is a case study with an ethnographic approach that also dialogues with university extension guidelines (2018). The experience was attended by members of the association and a student from the Production Engineering course at the Universidade do Estado de Amazonas (UEA), who was a resident of the community and a participant in the extension project. Interviews were used to gather data, through communication technologies such as WhatsApp. Secondary data were collected through the City of Manaus newspaper. Through this experience, it was observed that the AMISM has reinvented itself in relation to its planning and productive organization, producing face coverings and protective products from the forest, turning to the sustainable axis in the preparation of alcohol-based hand sanitizers mixed with aromatic herbs, with the knowledge and aromas of the forest, based on knowledge passed down from the ancestors. To this end, the Association appropriated the social networks Facebook and Instagram, to promote and sell its products to tourists and residents. In the field of egalitarian work, the UEA contributed by giving social returns to the community, through its extension activities, and by reaffirming the role of the student in training, in an integral and responsible way, faced with the emerging problems of the 21st century.
\end{abstract}

\section{Keywords:}

Sateré-Mawé

Sustainability

Indigenous crafts

University Extension 


\section{INTRODUCTION}

The Sateré-Mawé Indigenous Women's Association (AMISM) is located at rua São Marçal, in the district of Compensa II, Manaus, Amazonas. It was created in 1993 and served as a shelter for families who arrived in Manaus from the rural villages but had nowhere to live in the city. Its founder was Ms. Zenilda Silva, who died in 2007. The association now has its own space, in a large area that gathers ten families.

For Carvalho (2019), the association has a historical, political and social trajectory that belongs to the hwi/ Hiwy clan, which means "hawk". These are descendants of the family of Mrs. Zelinda Silva, who arrived in Manaus in the 1970s. Matos (2003, p. 52) confirms that "the initial creation of the AMISM was linked to the history of a Sateré-Mawé family that migrated to Manaus in the 1970s ... D. Tereza Ferreira da Silva". According to Mrs. Sônia Silva, current President of the AMISM (2020), before the Pandemic, the Association earned a living from the production of indigenous handicrafts, which were sold to tourists at events exhibitions such as fairs, and in the public squares and spaces of government institutions.

For the president of the AMISM, "the production of handcrafted articles, although small, contributes to the family income of the women of the group. Part of this income is invested in the purchase of raw materials for the manufacture of handicrafts, and the profit is divided up and used to support families". All the production is done by indigenous women, who use the proceeds not only to support their families, but also with the mission of preserving the mythological cultural aspects expressed in their art, as identity marks of ethnic origin (Carvalho, 2019).

In 2020, the world scenario affected by the pandemic caused the association of Sateré-Mawé artisans to seek new strategies to market their products and ensure the livelihood of their families. During this period, sales of products to tourists and all other sales channels were suspended.

According to data from the Ministry of Health, in December 2019, an outbreak of pneumonia caused by a new coronavirus - a family of viruses causing respiratory infections due to covid-19 disease - occurred in Wuhan, Hubei province, and spread rapidly throughout China, with an imminent risk of a pandemic, which did, in fact, occur.

According to data from the Ministry of Health (2020), the first case of Covid-19 in Brazil was confirmed on February 26, 2020. On March 3, there were 488 suspected cases reported in the country, 2 confirmed cases, and 240 cases ruled out, with no evidence of local transmission. In the state of Amazonas, according to data from the Health Surveillance, the first case occurred on March 13, 2020, and in the same month, the first death occurred: a resident of the municipality of Parintins who died in the city of Manaus. Until that period, the population of Amazonas had no concept of the real impacts that the disease would have.

On March 16, 2020, the government of Amazonas declared a state of emergency, through Decree 42,061/2020, which suspended non-essential activities. The Universidade Estadual de Amazonas also followed the the Decree, and the guidelines of the bodies responsible for health. As a result, the academic activities were suspended or moved to digital communication and information platforms.

Even with the suspension of activities, the teachers mobilized campaigns to serve the public through outreach activities. The contributions were focused on health, prevention against the virus, and guidance on organization and financial and procedural planning for the new procedures to be adopted.

Among the various non-governmental institutions, we chose the AMISM for this study, as it is an association of indigenous artisan women with whom the Universidade do Estado de Amazonas (UEA) has been in dialogue for more than seven years in the field of research, teaching and extension. As a result of Covid-19, the AMISM needed to create strategies of financial adaptation, becoming the line of analysis expressed in this report.

\section{PROBLEM AND RELEVANCE}

In this year marked by the coronavirus, which caused chaos in the health systems around the world, we sought to interact as extension students, by asking the questions: how is the AIMSM maintaining itself in the current context? and What services are being performed to serve tourists? This survey was carried out by an indigenous student of the Industrial Engineering course, a member of the Association, with the aim of describing the routine of the Sateré-Mawé Indigenous Women's Association in the context of the Covid-19 Pandemic.

In terms of social return, or giving back to the community, the University continues to fulfil its role by dialoguing and participating in activities promoted by the government of Amazonas. Another type of action was the voluntary service, in which teachers and students were mobilized to provide assistance to everyone who needed it. Thus, this report will show the importance of extension activities for teachers, students and the community, created as a two-way action.

\section{METHODOLOGY}

The case study, according to Olsen (2015), is a flexible 
and necessary approach in the field of complex studies. As for the composition, we agree with the considerations made by Eco (2014), in which the case is approached through the researcher's sensitivity. In this perspective, the author proposes that it is necessary to apprehend the phenomenon in a different sense, interpreting it by logical inferences, i.e., by an investigation method in which perceptions and logical reasoning are associated.

The field of action of the participants in this study was at the Sateré-Mawé Indigenous Women's Association, located in the urban area of Manaus/Amazonas, Brazil. The informants were selected according to their availability to participate in the interviews, conducted using technology (Creswell, 2010).

The questions that guided the study were: a) What was the Association's main activity before the Pandemic? How were they motivated to produce masks and iconographic products with the theme of the Sateré-Mawé cultural tradition? What are the new strategies for survival in the city of Manaus?

The choice of theme was motivated by the fact that this association needed to reinvent itself in the midst of the pandemic, serving not only tourists, as its customers who had previously purchased its handicrafts, but also making protective face coverings against Covid19, while keeping the cultural tradition alive. This study had tree participants, including the extension student from the UEA.

The study was based on ethnography, an approach that brings contributions to the field of qualitative research. On the subject of ethnographic research, Geertz states that "it guides the researcher in the selection of informants, in the establishment of relations with the community, in addition to guiding the mapping and construction of the field activities diary" (2008, p. 17).

The data collection was carried out in two phases: the first consisted of bibliographic research on the database platforms Ebsco, Scielo, reading Technical Notes on Covid-19, No. 002 28/04/2020, in order to support the theoretical basis. The second phase was a study of the Association's routine from March 18 to April 30, 2020.

The data collection techniques were participant observation, with the purpose of interacting through dialogues using technology. For this, we use the WhatsApp application, as well as selected photographs from the association's Facebook and Instagram pages, "on the web or on the internet", as Creswell states (2010, p. 179), with the due consent of the participants (OLSEN, 2015 ). Based on Bardin (2016), the data collected were organized into categories based on certain criteria, transcribed in the light of Content Analysis. The data were then interpreted, and the case written up in textual form.

All the clauses of the Informed Consent Term (ICF) and the authorizations were respected. As regards ethical issues, this study has a project registered with the Research Ethics Committee under CAAE No. 14818919.2.0000.5016, meeting the requirements of the Research Ethics Committee resolutions (Creswell, 2010).

\section{RESULTS}

Extension projects of Higher Education Institutions, such as the Universidade do Estado do Amazonas, have been essential to expand the understanding of emerging issues among those involved in the extension projects, In this case, the selection of an association for strengthening artisans - the Sateré-Mawé Indigenous Women's Association - was to understand the space experienced in the context of Covid19.

We saw that since its creation, the AMISM has worked with Sateré-Mawé indigenous women in the production of handicrafts for the tourist market, selling their products all over Brazil, from the north to the south, and even exporting to Europe. Figure 1 shows some items on display (A) and (B) and the direct contact with the tourist $(C)$ and $(D)$ - these photos were all taken before the pandemic.

\section{Figure 1 - AMISM production (pre-pandemic)}
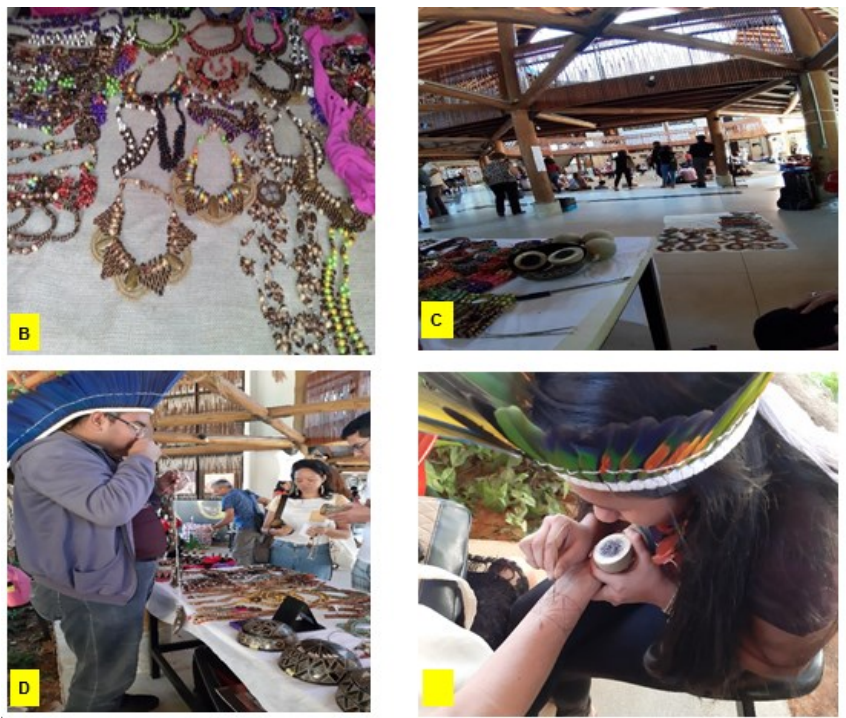

Source: Carvalho (2019).

With the arrival of the Covid-19 Pandemic, due to the potential impacts on health and the economy, the group needed to look for alternatives to survive, even facing moments of anguish and uncertainty. With the help of extension volunteers from the Uni- 
versidade do Estado de Amazonas and friends of the Association, it was able to collect basic baskets, alcohol and sewing machines for the production of a thousand masks, initially. The masks were sent to villages in the upper Rio Negro, $990 \mathrm{~km}$ from Manaus (in a straight line), according to data from Google maps.

According to Ms. Sônia Silva, the incentive for the production of ecological masks and bags came from friends in the United Kingdom, who donated sewing machines to start the production. "Our mission is to empower Sateré women, in search of better living conditions, in addition to helping to support families," said Samela Silva (2020), daughter of the Association's president.

The Association also benefited from the contribution of a student of the Production Engineering course (UEA/EST), Rucian da Silva, an extension volunteer and son of the current President of AMISM, Mrs. Regina Vilácio. Rucian said in an interview: "I am using the tools of the Production Engineering course, such as planning and organizing work". Honing the knowledge of teaching, together with extension activities, has positive results as students are able to masterfully mediate the extension field, giving back to the community.

Other partnerships were formed with teachers from different units of the UEA. In this context, guidelines and donations of hygiene and prevention materials were made available; the implantation and dissemination of telehealth/AM, medical and psychological assistance by chatbot, and the use of the SASI application, in addition to the data transfer and monitoring system between Universidade Estadual de Amazonas and the Health Surveillance Foundation (FVS), with a total of 257 participants, including students and teachers.

During the pandemic, the Sateré-Mawé indigenous people lost some of their indigenous leaders, such as Mr. Otavio dos Santos, who died on March 16, 2020, aged 67, at the beginning of the Pandemic. His death was due to coronavirus infection in the village of São Benedito, which is located on the Marau river, in the municipality of Maués, 641 kilometers from the capital of Amazonas, according to the newspaper Amazônia Real (2020). Otavio dos Santos was a tuxaua from the village, and left knowledge of ancestry to those who lived with him. Thus, the entire nation of Sateré blood is suffering, but it has sought the strength to maintain its cultural traditions, even in the current scenario.

In Manaus, the AMISM works with handicrafts using elements from the tradition of the Sateré-Mawé people, and raw materials such as seeds, herbs and straw from indigenous lands (Terras Indígenas - TI). According to Rucian da Silva, after cutting the raw material, the pieces are transformed into handicrafts by artisans and are "sold in public squares in Manaus, in hotels, and in stores in the commercial shopping malls".

As a result of Covid-19, the government of the State of Amazonas suspended all non-essential commercial activities. The Association, which survives from the production of handicrafts, suffered economic impacts and was forced to seek alternative ways to support their families, through adaptive replanning.

In an interview with the international broadcaster Clarin (France, 5/13/2020), one of the artisans declared that "the production of the masks is sufficient to guarantee the people's livelihoods". For the extension worker, Rucian Vilácio, "the satisfaction is to maintain the security of the people's health and to help others, needy people who cannot afford to buy the masks". These facts attracted the attention of the national and international press about the moment of innovation, in the face of Pandemic, as shown in Figure 2.

Figure 2 - The French press being received by the indigenous student

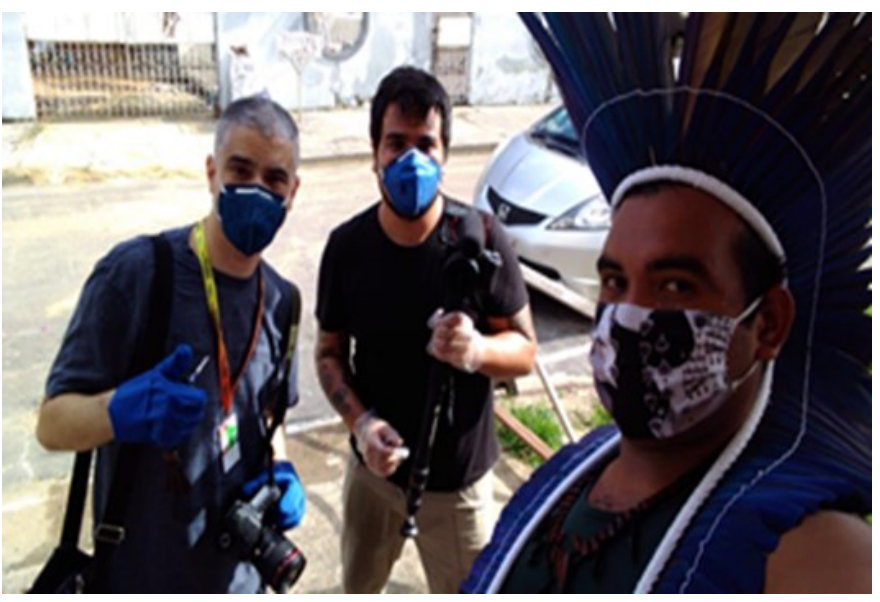

Source: Rucian da Silva Vilácio with a team of journalists (Clarin.com 05/13/2020).

With the Pandemic, the Association established new contacts for an atypical moment, having to reinvent itself, using networks such as Facebook (AMISM Sateré -Mawé) and Instagram (@amism_satere-mawe) to boost its business. Thus, the production of protective masks in fabric reflects indigenous knowledge in the current context, as well as the preparation of alcoholbased sanitizers mixed with aromatic herbs from the Amazon, marked by indigenous knowledge.

For the members of the association, production is based on the principles of sustainability: economic, environmental, social and cultural, in the treatment of urban issues. Thus, the job requires discipline, because "there is a deadline for delivery, in addition to the fact that the virus has spread very quickly, and people are in a hurry for the masks", highlighted President Regina Vilácio. "The idea of sustainability is thus applied to the conditions for reproducing the legitimacy of urban policies," according to Acselrad (1999, p. 85). In this scenario, the organization established internal criteria to keep pace with the city of Manaus. The president also stressed that, "at the beginning it was very diffi- 
cult, it was necessary to change the strategies in order to feed ten families, but we had to face the moment".

On the other hand, this new work is providing a livelihood for the artisans, which, according to the president of the Association, was difficult at the beginning, "I was very concerned, because our custom was to make handicrafts, our public is tourists, everything was closed, and the families live from the handicrafts ". By redesigning the activities, logistics and the flow of the production process, through cooperative work, the production of services grew, other types of orders emerged, such as masks with ethnic designs. Thus, without detaching themselves from the identity of the Sateré-Mawé indigenous people, it was possible to innovate in order to serve customers, as shown in Figures 3 and 4.

Figure 3 - Raw materials used in the handicrafts

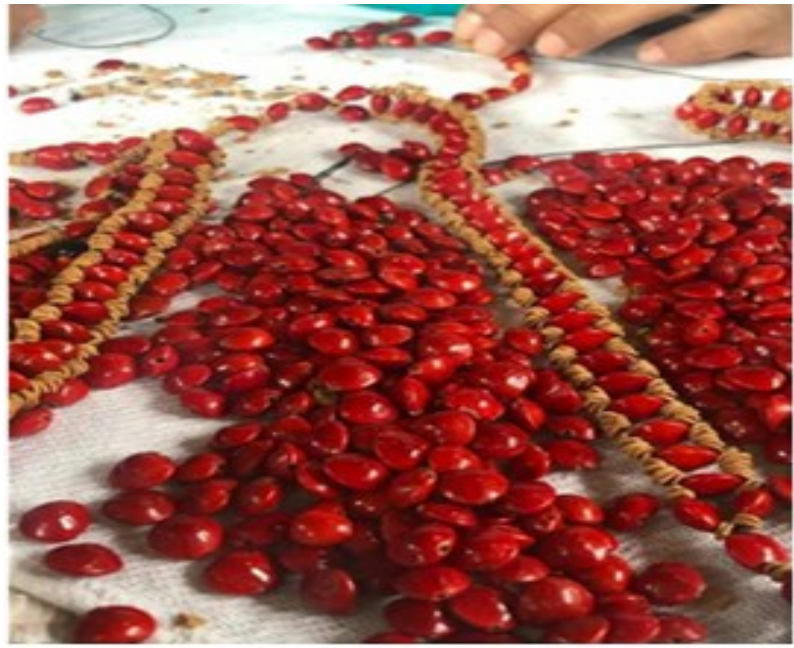

Source: AMISM Instagram (2020).

Figure 4 - Identity: concern with the present

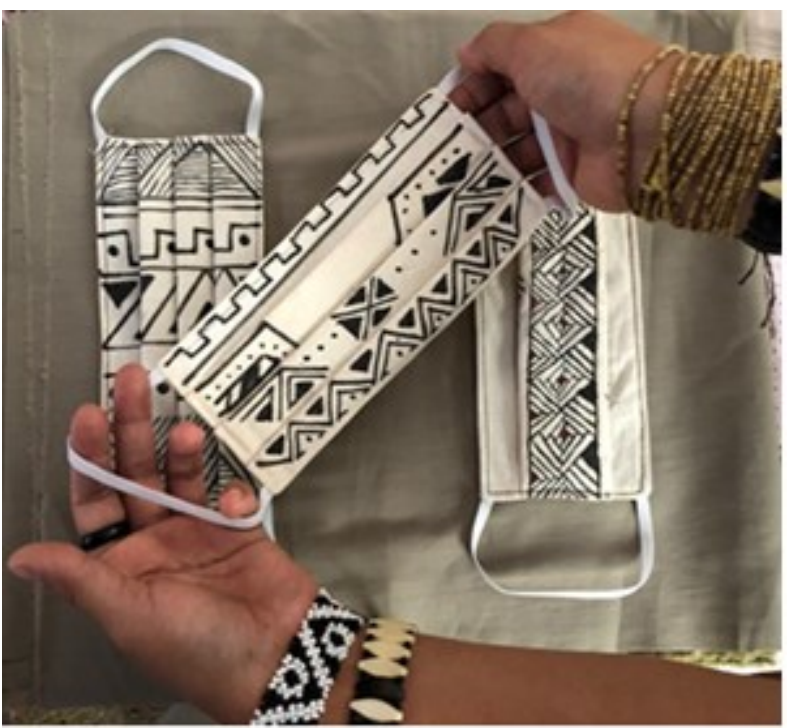

Source: AMISM Instagram (2020).
For the student, Rucian da Silva, the whole management of handicrafts, protective masks and alcoholbased sanitizers are processes experienced with the members that have generated learning. The articulated knowledge is diverse, stimulating autonomy, administration and the elaboration of new flowcharts of services, processes and resources, and including logistics with an interdisciplinary view, within the knowledge of the Industrial Engineering course.

\section{PRACTICAL IMPLICATIONS AND CONCLUSIONS}

In this report of experience, we prioritize the study of the Sateré-Mawé Indigenous Women's Association, an indigenous community that looked for alternatives in order to survive in the context of the Covid-19 pandemic. Using its diversified, ancestral knowledge, the association managed to manage concerns about the world, promoting solidarity among other peoples in the state of Amazonas.

We consider this to be an innovative study, as it shows the case of an atypical global moment, the Covid-19 pandemic, and how it affected indigenous peoples who live in situations where there is little outside support. It is hoped that this study will provoke concerns and reflections on alternative work, focusing on handicraft services for tourists.

A work of knowledge of the artisan, who polishes and files the pieces (Figure 5), retaining their rustic charm, for the production of protective face masks (Figure 6), which required academic knowledge of the process flow.

Figure 5 - Handicrafts

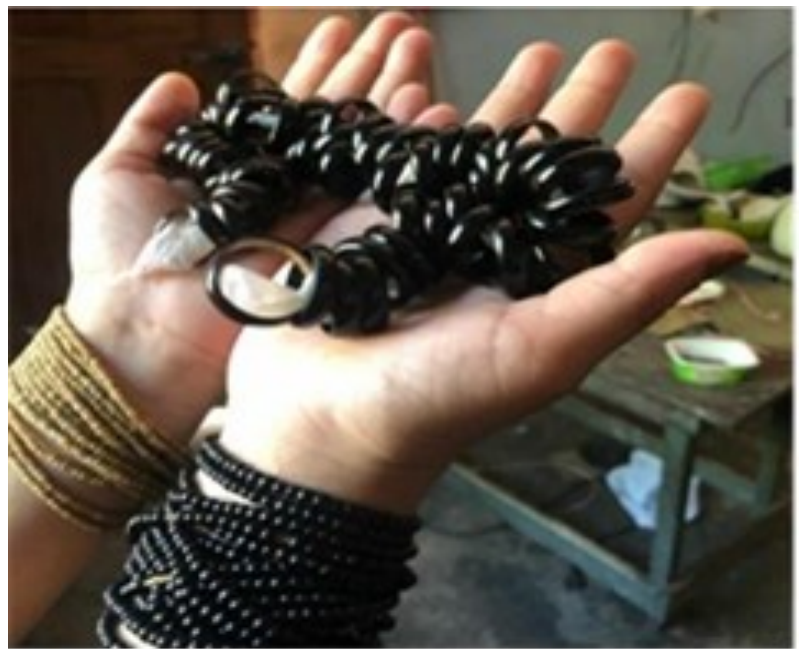

Source: AMISM Instagram (2020). 
Figure 6 - Protective face masks

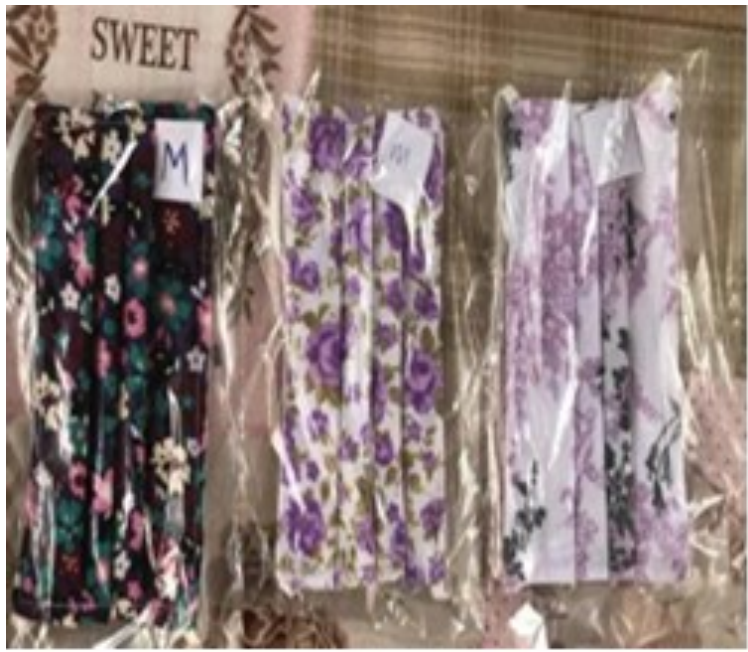

Source: AMISM Instagram (2020).

We saw that the use of technologies is a strong ally for expanding the services in a responsible and conscious way, for tourists who are interested in purchasing products made by indigenous artisans. We highlight four reasons for this: 1 ) it is raw material from nature; 2 ) it is made by the indigenous people themselves; 3 ) it is a way of valuing the culture of a people and 4) it is done using sustainable practices.

Therefore, this study enables a dialogical, theoretical and practical process in the area of cultural tourism, in an interdisciplinary way, between the AMISM and Universidade Estadual de Amazonas. This process involved interacting, acting as protagonist, and stimulating the artisans' know-how, rooted in the articulated tripod of the inseparability of teaching, research and extension. It also enables reflection on the role and training of the academic citizen, in an integral and responsible way, in the face of the emerging problems of the 21st century, which instigates us to think about tourism responsibly, in a way that protects the planet and all those who live on it.

\section{REFERENCES}

Acselrad, Henri. (1999). Discursos da sustentabilidade urbana. Revista Brasileira de Estudos Urbanos e Regionais.

Amazonas. Imprensa Oficial. Available at: https://ediariooficial.com/diario-oficial-do-estado-doe / amazonas/ gclid=CjwKCAjwkun1BRAIEiwA2mJRWcCvWyY4 nufNN2ilOzFAvQ34jO 2 3gTvll1Akw2d-r7-r8ttRdxNxoCPPkQAvD_BwE. Accessed on: May 12, 2020 .
Bardin, L. (2016). Análise de Conteúdo (3 ed.). Edições 70

Carvalho, Joelma Monteiro de. (2019). Ritual de passagem: das terras indígenas às áreas urbanas dos Sateré-Mawé Manaus, (AM): editora UEA. Ebook. Available at: repositório institucional.uea.edu.br/handle/riuea/1566. Accessed on Feb. 25, 2020.

Creswell, J. (2010). Projeto de Pesquisa métodos qualitativos, quantitativos e mistos. Tradução Magda Lopes. $3^{\mathrm{a} e d}$. Porto Alegre: Artmed.

Geertz , Clifford. (2008). A interpretação das culturas. 1.ed. 13 reimp. Rio de Janeiro: LTC.

Clarín. Brasil: de las artesanías a los barbijos, cómo sobreviven al coronavirus los indígenas del Amazonas. Available at: https://www.clarin.com/mundo/ brasil-artesanias-barbijos-sobrevivencoronavirus-indigenas-

amazonas 0_9 XOH3lsH.html. Accessed on May $13,2020$.

Matos, Maria do Socorro Paço de. (2003). O olhar das mulheres Sateré-Mawe sobre o lixo. Dissertação. Mestrado em Sociedade e Cultura na Amazônia. Programa de Pós-Graduação em Sociedade e Cultura e Cultura. UFAM: Manaus.

Universidade do Estado do Amazonas. (2020). Nota téc nica Covid-19, n. ${ }^{\circ} 002$ 28/04/2020. Disponível em: $\quad$ http://www.sedecti.am.gov.br/ enfrentamento-ao-covid-cientistas-contribuemcom-estudos/. Accessed on: May 18, 2020.

Olsen, Wendy. (2015). Coleta de dados: debates e métodos fundamentais em pesquisa social. Penso Editora.

Brasil. Ministério da Educação. (2018). Diretrizes da extensão universitária. Brasília. Disponível:http:// portal.mec.gov.br/index.php? op-

tion $=$ com_docman\&view $=$ download\&alias $=1042$ 51-rces007-18\&category_slug=dezembro-2018pdf\&Itemid=30192: Accessed on: May 12, 2020.

Brasil. Ministério da Saúde. (2020). Coronavírus (Covid19). Portal do Ministério da saúde. Available at: https://coronavirus.saude.gov.br/sobre-adoenca. Accessed on: May 12, 2020. 